\title{
INTERPRETING ERISA: CORPORATE OFFICER LIABILITY FOR DELINQUENT CONTRIBUTIONS
}

The Employee Retirement Income Security Act of 1974 (ERISA) ${ }^{1}$ comprehensively regulates private employee pension plans and almost completely preempts the field of private employee pension plan regulation. ${ }^{2}$ Section 515 of ERISA, ${ }^{3}$ entitled "delinquent contributions," imposes a duty on "employers" to make all necessary contributions to multiemployer pension plans in accordance with plan agreements or collective bargaining agreements. ${ }^{4}$ Section 502 allows a participant, benefi-

1. Pub. L. No. $93-406,88$ Stat. 829 (codified as amended at 29 U.S.C. $\S \S 1001-1461$ (1982)) [hereinafter ERISA].

Congress enacted ERISA, the culmination of more than a decade of governmental study, see $D$. McGill, Fundamentals of Private Pensions 33-36 (3d ed. 1975), in response to a massive growth in private pension plans and the apparent inability of the existing law to control abuse in private pension plan administration. See H.R. REP. No. 533, 93d Cong., 1st Sess. 1, 3, reprinted in 1974 U.S. Code CoNG. \& ADMIN. News 4639, 4641. The Committee stated that membership in private pension plans had increased from twenty-one million employees in 1960 to thirty million employees in 1974. The Committee estimated that the assets of private pension plans totaled more than $\$ 150$ billion in 1974. Id.

ERISA is divided into four titles. Title II contains the tax aspect of ERISA; its provisions amend the Internal Revenue Code as it relates to pensions and retirement accounts. Title III contains miscellaneous "housekeeping" provisions, includiug jurisdictional and administrative rules. Title IV establishes the Pension Benefit Guaranty Association and contains provisions pertaining to retirement plan termination insurance.

Title I, however, contains the essence of ERISA because its provisions protect employee rights. Title I establishes specific reporting and disclosure requirements, participation and vesting standards, minimum funding standards, and fiduciary standards. It also contains administration and enforcement provisions. Because employers to some extent fund private pension plans, Title l's enforcement provisions ensure that employer contributions continue.

2. Section 514(a) of ERISA, 29 U.S.C. § 1144(a) (1982), provides that "the provisions of this subchapter and subchapter III of this chapter shall supersede any and all State laws insofar as they may now or hereafter relate to any employee benefit plan." ERISA does not preempt state insurance, banking, regulated securities, or criminal laws. ERISA $\$ 514(b)(2)(A),(b)(4), 29$ U.S.C. $\S 1144(\mathrm{~b})(2)(\mathrm{A}),(\mathrm{b})(4)(1982)$.

3. ERISA § 515, 29 U.S.C. § 1145 (1982).

4. Id. Section 515 provides:

Every employer who is obligated to make contributions to a multiemployer plan under the terms of the plan or under the terms of a eollectively bargained agreement shall, to the extent not inconsistent with law, make such eontributions in accordance with the terms and conditions of such plan or such agreement.

Id. 
ciary, or fiduciary of the plan to bring civil enforcement actions against the plan or the "employer."s

In defining "employer" under section 515, courts have reached different results. Some courts have allowed employees to bring actions against either the funding corporation or one of its corporate officers. ${ }^{6}$ Other courts have refused to define "employer" as broadly and have held corporate officers personally hable only in cases in which the facts warrant a piercing of the corporate veil. ${ }^{7}$

This note first discusses these two competing interpretations of section 515.8 It then examines the text of sections 502 and 515, their legislative history, their purpose, and the relationship between them and ERISA's other provisions. The note concludes that courts should not consider a corporate officer an "employer" under sections 502 and 515 and therefore should not hold the officer personally hable for delinquent contributions unless the circumstances warrant a piercing of the corporate veil. ${ }^{9}$ The note also discusses other situations in which courts can hold an officer personally liable for violations of ERISA. ${ }^{10}$

\section{The CONFlicting INTERPRETATIONS OF SECTION 515}

To date, nine cases have specifically addressed whether a corporate officer is an "employer"-five decisions in the Third Circuit refusing to hold an officer personally hable absent facts supporting a piercing of the corporate veil, 11 and four district court decisions in the First Circuit holdimg that an officer can be an "employer" and thus personally hable

5. Id. $\S 502,29$ U.S.C. $\S 1132$.

6. See infra notes 22-32 and accompanying text.

7. See infra notes 13-21 and accompanying text. The equitable process of "piercing the corporate veil" allows a court to disregard the corporate entity and hold shareholders personally hable for the liabilities of the corporation. Courts have considered a number of factors in determining whether to pierce the veil: (1) whether the corporation was "grossly undercapitalized for the purposes of the corporate undertaking," DeWitt Truck Brokers, Inc. v. W. Ray Flemming Fruit Co., 540 F.2d 681, 685 (4th Cir. 1976); (2) whether the incorporators had a "fraudulent intent," Audit Servs., Inc. v. Rolfson, 641 F.2d 757, 764 (9th Cir. 1981); (3) whether the facts "present an element of injustice or fundamental unfairness," DeWitt, 540 F.2d at 687 ; (4) whether the corporation in reality maintained a separate identity from the shareholders, Audit Servs., 641 F.2d at 764; DeWitt, 540 F.2d at $686-87$; and (5) whether corporate formalities are observed. Id. at 686-87; Lakota Girl Scout Camp Council, Inc. v. Havey Fund-Raising Management, Inc., 519 F.2d 634, 638 (8th Cir. 1975).

Generally, no one of the above factors, by itself, is determinative. See, e.g., Walkovszky v. Carlton, 18 N.Y.2d 414, 420-21, 223 N.E.2d 6, 9-10, 276 N.Y.S.2d 585, 590-91 (1960).

8. See infra notes $11-32$ and accompanying text.

9. See infra notes 33-76 and accompanying text.

10. See infra notes $77-96$ and accompanying text.

11. Solomon v. Klein, 770 F.2d 352 (3d Cir. 1985); United Paper Workers Int'l Union v. Arlington Sample Book Co., No. 83-2828, slip op. (E.D. Pa. May 23, 1984); Amalgamated Cotton Garment \& Allied Indus. Fund v. J.B.C. Co., 608 F. Supp. 158 (W.D. Pa. 1984); Combs v. Indyk, 554 F. Supp. 573 (W.D. Pa. 1982). 
even when circumstances do not warrant a piercing of the corporate veil. ${ }^{12}$

In the first of these decisions, Combs v. Indyk, ${ }^{13}$ the plaintiff, a trustee of the plan, brought an action under section 515 against the officers of the then-bankrupt corporation, seeking to recover delinquent contributions owed the plan. ${ }^{14}$ The district court refused to impose section 515 hability on the corporate officers, noting the absence of evidence supporting a piercing of the corporate veil. ${ }^{15}$ The court reasoned that although the definition of "employer" in section $3(5)^{16}$ included "person," the definition of "person" in section 3(9)17 did not include "officer." 18 Furthermore, the court asserted that Congress did not intend "to expose corporate officers to liability for their employers' violations of ERISA."19 Combs was followed in three subsequent district court decisions, ${ }^{20}$ as well as in a decision by the United States Court of Appeals for the Third Circuit. ${ }^{21}$

Four district court decisions in the First Circuit have reached an

12. Alman v. Frank's Sportswear Co., 6 Employee Benefits Cas. (BNA) 2798 (D. Mass. 1985); Rubenstein v. Tri-State Transp., Inc., 6 Employee Benefits Cas. (BNA) 2372 (D. Mass. 1984); Massachusetts State Carpenters Pension Fund v. Atlantic Diving Co., No. 83-2872, slip op. (D. Mass. Oct. 12, 1984); Alman v. Servall Mfg. Co., No. 82-0746, slip op. (D. Mass. Apr. 9, 1984).

13. 554 F. Supp. 573 (W.D. Pa. 1982).

14. Id. at 574 .

15. Id. at 575 .

16. The full defimition states that an "employer" is "any person acting directly as an employer or indirectly in the interest of an employer, in relation to an employee benefit plan." ERISA §3(5), 29 U.S.C. $\S 1002(5)$ (1982).

17. The full definition states that a "person" is "an individual, partnership, joint venture, corporation, mutual company, joint-stock company, trust, estate, unincorporated organization, association, or employee organization." ERISA § 3(9), 29 U.S.C. § 1002(9) (1982).

18. Combs, 554 F. Supp. at 575.

19. Id.

20. In United Paperworkers Int'1 Union v. Arlington Sample Book Co., No. 83-2828, slip op. (E.D. Pa. May 23, 1984), the plan brought a section 515 action against the corporation and the corporation's president, who was also the sole shareholder. Citing Combs, the court refused to hold the president liable under section 515, stating that "the mere status as owner or officer of an employer-corporation does not also transform that individual into an employer under ERISA." Id. at 7. In Amalgamated Cotton Garment \& Allied Indus. Fund v. J.B.C. Co., 608 F. Supp. 158 (W.D. Pa. 1984), the fund brought a section 515 action against both the corporation and its principal officers, alleging that the officers were jointly and severally liable with the corporation. Id. at 160 . Adopting the reasoning of Combs, the court stated that the fact that the defendants were officers of the employer-corporation "[did] not, in and of itself, confer liability." Id. at 167. The court concluded that the officers could not be held liable under section 515 for the corporation's ERISA violations absent facts that would warrant a piercing of the corporate veil. Id. Finally, in Sheet Metal Workers Local 19 v. Laing Sheet Metal, No. 85-1383, slip op. (E.D. Pa. Nov. 26, 1985), the court dismissed section 515 claims brought against defendant officers.

21. The United States Court of Appeals for the Third Circuit faced the issue of whether an officer is an "employer" in Solomon v. Klein, 770 F.2d 352 (3d Cir. 1985). In that case, a trustee brought an action for delinquent contributions against Klein, "the holder of 50 percent of the stock of a company [andl the president and chief executive officer." Id. at 353. The court refused to adopt 
opposite conclusion. ${ }^{22}$ The second of these decisions, Massachusetts State Carpenters Pension Fund v. Atlantic Diving Co., ${ }^{23}$ contains the most detailed analysis. ${ }^{24}$ In that case, the court granted the plaintiff's motion

the approach taken in Massachusetts State Carpenters Pension Fund v. Atlantic Diving Co., No. 832872, slip op. (D. Mass. Oct. 12, 1984), and instead adopted the Combs analysis. The court stated:

We are not impressed by the Massachusetts district court's analysis. It relied not on the interpretation of the ERISA statute but on the Fair Labor Standards Act and precedents of the First Circuit.... The method of analogy is, of course, a legitimate method of reaching a decision. But in matters of statutory construction of ERISA our responsibility is to ascertain the intention of Congress in ERISA and not its intention in enacting a separate federal statute.

Id. at 354-55.

The United States Court of Appeals for the District of Columbia Circuit has recently been drawn into the fray on a related issue. In Connors v. P \& M Coal Co., 801 F.2d 1373, 1377-78 (D.C. Cir. 1986), the court held that corporate officers were not liable under ERISA's withdrawal liability provisions, ERISA $\S 4201,29$ U.S.C. $\S 1381$ (1982), unless the facts warranted a piercing of the corporate veil. In reaching its conclusion, the court held that officers were not "employers" under section 4201, citing Combs and Solomon as support. Id.

22. See supra note 12.

The United States Court of Appeals for the First Circuit recently affirmed a district court's imposition of personal liability on shareholders, who were also corporate officers, in a section 515 case. In Alman v. Danin, 801 F.2d 1, 4 (1st Cir. 1986), the court of appeals agreed with the lower court that the circumstances warranted a piercing of the corporate veil, and did not reach the question whether an officer would be personally liable in other circumstances. The court suggested, however, that the corporate veil can be inore readily pierced when the action is for delinquent contributions under section 515 :

ERISA, the statute sought to be enforced here, cannot be said to attach great weight to corporate form. Indeed, deferring too readily to the corporate identity may run contrary to the explicit purposes of the Act. Congress enacted ERISA in part because many employees were being deprived of anticipated benefits, which not only reduced the financial resources of individual employees and their dependents but also undermined the stability of industrial relations generally. Allowing the shareholders of a marginal corporation to invoke the corporate shield im circumstances where it is inequitable for them to do so and thereby avoid financial obligation to employee benefit plans, would seem to be precisely the type of conduct Congress wanted to prevent.

Id. at 3-4 (citations omitted). Thus, Danin supports the four district court decisions imposing liability on corporate officers insofar as it implies that the corporate veil affords officers little protection in section 515 cases.

23. No. 83-2872, slip op. (D. Mass. Oct. 12, 1984).

24. In Alman v. Servall Mfg. Co., No. 82-0746, slip op. (D. Mass. Apr. 9, 1984), the court held the defendant chief executive officer, Herman Bank, personally liable for the contributing corporation's section 515 violations. The court stated:

Herman Bank was a corporate officer and principal shareholder of Servall during the relevant time period. As chief executive officer of Servall, he had control of its operations and he managed and directed all its financial, production and all other business activities. He acted on behalf of Servall in all inatters having to do with the benefit plans, including audits, ascertaining contributions and collection arrangement. Therefore, I conclude that ... he is an employer within the meaning of the Act.

Servall, slip op. at 2-3. As support for this conclusion, the court cited Donovan v. Agnew, 712 F.2d 1509 (1st Cir. 1983), a case decided under the Fair Labor Standards Act of 1938, 29 U.S.C. §§ 201219, 557 (1982). Donovan held that corporate officers were "employers" within the meaning of the Fair Labor Standards Act. 712 F.2d at 1511. The Servall court did not elaborate on the relationship between ERISA and the Fair Labor Standards Act.

In Rubenstein v. Tri-State Transp., Inc., 6 Enployee Benefits Cas. (BNA) 2372 (D. Mass. 1984), the court held that an officer was an "employer" and therefore liable under section 515 . The 
to amend the section 515 complaint to include the officers of the contributing corporation, specifically rejecting the Combs analysis. ${ }^{25}$ The basis for the court's decision was an analogy to the Fair Labor Standards Act of $1938,{ }^{26}$ under which courts have imposed liability on officers, as "employers," for minimum wage violations. ${ }^{27}$ The court noted (1) that both ERISA and the Fair Labor Standards Act are "protective" of compensation, ${ }^{28}$ (2) that the goals behind the enactment of the two Acts are the same, ${ }^{29}$ and (3) that the definitions of "employer" and "person" are very similar under both Acts. ${ }^{30}$ In light of these considerations, the court concluded that both ERISA and the Fair Labor Standards Act should be interpreted in the same fashion. ${ }^{31}$ The court emphasized that under ERISA, as under the Fair Labor Standards Act, a court should look to the "economic realities" in the employer-employee relationship when determining who is an "employer," rather than to "corporate terminology and titles." 32

\section{Corporate OfFicer Liability UNDER Section 515}

\section{A. Is an Officer an 'Employer"?}

The issue of whether a corporate officer is hable for the corporation's delinquent pension contributions will have significant impact on corporate operations, the use of director and officer insurance, the structure of pension plans, and the role of corporate officers in the function of pension plans. In order to interpret whether an officer is an "employer" under ERISA, courts inust examine the statute's text, legislative history, purpose, and surrounding provisions. ${ }^{33}$

court emphasized the officer's $80 \%$ ownership interest in the corporation and his extensive managerial activities. Id. at 2374. Finally, in Alman v. Frank's Sportswear Co, 6 Employee Benefits Cas. (BNA) 2798 (D. Mass. 1985), the court denied an officer's motion for summary judgment in a suit brought under section 515. The court stated that "corporate form does not shield an officer ... whose role makes him an 'employer' under [section 515] of ERISA." Id. at 2801.

25. Atlantic Diving, slip op. at 14.

26. 29 U.S.C. $\$ \S 201-219,557$ (1982).

27. See infra note 42 .

28. Atlantic Diving, slip op. at 9-10.

29. Id. at 9.

30. Id.

31. Id. at 10.

32. Id. at 10-11. The court made no mention of congressional intent.

33. The Supreme Court has stated:

[I]t is well settled that, in interpreting a statute, the court will not look merely to a particular clause in which general words may be used, but will take in connection with it the whole statute (or statutes on the same subject) and the objects and policy of the law, as indicated by its various provisions, and give to it such a construction as will carry into execution the will of the legislature, as thus ascertained, according to its true intent and meaning.

Brown v. Duchesne, 60 U.S. (19 How.) 183, 194 (1857). 
1. Text of Sections 3 and 515. Although a hiteral reading of the pertinent sections of ERISA might indicate that Congress intended to impose personal hability on an officer for a corporation's delinquent contributions, a close analysis of the language of these sections yields a contrary conclusion. Section 515 imposes a duty on an "employer who is obligated to make contributions to a multiemployer plan under the terms of the plan ... [to] make such contributions in accordance with the terms and conditions of such plan." 34 Section 3 defines "employer" as "any person acting directly as an employer, or indirectly in the interest of an employer, in relation to an employee benefit plan." 35 In turn, "person" is defined as "an imdividual, partnership, joint venture, [or] corporation."36 Thus, the definition of "employer" consists of two elements: (1) being a "person," and (2) "acting directly as an employer, or indirectly in the interest of an employer, in relation to an employee benefit plan."

The Third Circuit cases that refused to hold an officer personally hable under section 515 reached only the first prong: whether a corporate officer is a "person." 37 These cases refused to impose liability on the ground that a corporate officer caimot be an "employer" because "officer" is not listed in the definition of "person" in section 3. ${ }^{38}$ This position, however, is tenuous because Congress defined "person" to include "individual"- a term that is surely broad enough to encompass corporate officers. ${ }^{39}$

A corporate officer, however, cannot be an "employer" unless the second, more restrictive prong is met as well: the officer must be "acting directly as an employer, or imdirectly in the interest of an employer, in relation to an einployee benefit plan." The courts that have imposed personal liability on officers have given this second prong a very literal reading. These courts have indicated that the imtegral involveinent of corporate officers in corporate affairs is important in determining whether officers are themselves "employers." 40 Thus, these courts im-

34. ERISA § 515, 29 U.S.C. $\S 1145$ (1982).

35. Id. $\S 3(5), 29$ U.S.C. $\S 1002(5)$.

36. Id. § 3(9), 29 U.S.C. § 1002(9).

37. Solomon v. Klein, 770 F.2d 352, 353 (3d Cir. 1985); United Paper Workers Int'l Union v. Arlington Sample Book Co., No. 83-2828, slip op. at 6 (E.D. Pa. May 23, 1984); Amalgamated Cotton Garment \& Allied Indus. Fund v. J.B.C. Co., 608 F. Supp. 158, 166-67 (W.D. Pa. 1984); Combs v. Indyk, 554 F. Supp. 573, 575 (W.D. Pa. 1982).

38. See supra notes 16-18 and accompanying text.

39. See supra note 17.

40. See Alman v. Frank's Sportswear Co., 6 Employee Benefits Cas. (BNA) 2798, 2800-01 (D. Mass. 1985) (denying officer's motion for summary judgment that he was not an "employer"); Rubenstein v. Tri-State Transp., Inc., 6 Employee Benefits Cas. (BNA) 2372, 2374 (D. Mass. 1984) (defendant officer owned $80 \%$ interest, served as chief executive officer, was corporation's spokesman with the fund, and filed monthly reports with the fund); Massachusetts State Carpenters Pen- 
plicitly loold that such involvemeut amounts to "acting indirectly in the interest of" the corporation.

Sucli a broad interpretation of section 3 is inappropriate. Under a literal reading, any employee who is involved in the operation of a pension plan while working for the corporation would be an "employer." Thus a court could impose liability on the payroll accountants who post the contributions, the coinptrollers or financial officers who transfer funds, and even the personnel inanager, all of wliom act "indirectly in tlie interest of the employer in relation to an employee benefit plan." But no court would consider lolding these employees personally liable for violations of section 515 .

A more reasonable interpretation of the phrase "acting indirectly in the interest of an employer" is that Congress intended to include within the definition of "employer" those third-party corporations that act as agents of and provide employee benefit plan services for the contributing corporation. Under this interpretation, the phrase serves to preclude the contributing corporation from using third-party providers to escape the requirements of ERISA.41 Altlougl other interpretations of the phrase are possible, the language of this section does not directly authorize courts to lold officers personally liable for delinquent contributions under section 515.42

sion Fund v. Atlantic Diving Co., No. 83-2872, slip op. at 11 (D. Mass. Oct. 12, 1984) ("[P]ersonal liability [will be] imposed on a dominant corporate officer-shareholder [who is] integrally involved with a corporation's failure to honor pension fund obligations."); Alman v. Servall Mfg. Co., No. 820746, slip op. at 2 (D. Mass. Apr. 9, 1984) (stating that corporation's chief exeeutive officer was an "employer" because he managed and directed all of corporation's business affairs).

It is important to note that the standard used in these cases for finding "employer" status"integral involvement"- is not equivalent to a veil-piercing standard. "Integral involvement" only requires substantial ownership coupled with an exercise of control over the corporation. For a discussion of the veil-piercing standard, see supra note 7.

41. Cf. Insurance \& Prepaid Benefits Trusts v. Marshall, 90 F.R.D. 703, 705 (C.D. Cal. 1981) (private multiple employer trust not "employer" under ERISA because eorporate employers, whose employees are members of the trust, "possess no actual decision-making powers"), aff'd sub nom. Insurance \& Prepaid Benefits Trusts v. Donovan, 685 F.2d 443 (9th Cir. 1982), cert. denied, 459 U.S. 1103 (1983); Taggart Corp. v. Efros, 475 F. Supp. 124, 126 (S.D. Tex. 1979) (provider is not "employer" under ERISA if provider acts in its own interest or is not within eontrol of corporate employer), aff'd sub nom. Taggart Corp. v. Life Health Benefits Admin. Inc., 617 F.2d 1208 (5th Cir. 1980), cert. denied, 450 U.S. 1030 (1981); Bell v. Employee Sec. Benefit Ass'n, 437 F. Supp. 382, 392 (D. Kan. 1977) (private multiple employer trust not an "employer" under ERISA because it did not "act directly as, or indirectly for the benefit of, the employer of the individuals who purchased the plan"); Hamberlin v. VIP Ins. Trust, 434 F. Supp. 1196, 1198 (D. Ariz. 1977) (private multiple employer trust not an "employer" under ERISA because it was not aeting on behalf of or under control of corporate employer whose employees it solicited).

42. See Combs v. Sun-Up Coal Co., 634 F. Supp. 13, 17-18 (D.D.C. 1985) (holding that officers are not "employers" for purposes of ERISA section 4201 withdrawal liability and stating that the definition of "employer" in section 515 should not be read too literally). This argument, however, runs counter to the way courts have interpreted the Fair Labor Standards Act of 1938, 29 U.S.C. 
2. Legislative History. The legislative history of sections 502 and 515 sheds no hight on whether Congress intended to create officer liability for section 515 violations. 43 Nor does the legislative history contain a definition of "einployer." Congress simply did not discuss "corporate officers" or their liability. Although such silence does not negate the possibility of personal hability for officers, it does suggest that Congress did not intend to create such liability. ${ }^{44}$ Absent soine contrary indication of congressional imtent, ERISA should not be deemed to have abrogated the establislied principle tliat an officer is personally liable only when the plaintiff can pierce the corporate veil. 45

3. Policy and Purpose. Several courts assert that because botli ERISA and the Fair Labor Standards Act have similar compensatory purposes, ERISA should be interpreted, as has been the Fair Labor Stan-

$\S \S 201-219,557$ (1982). Under the Fair Labor Standards Act, courts have applied a literal interpretation of the term "employer" and have held officers jointly and severally liable along with the corporation. See, e.g., Donovan v. Agnew, 712 F.2d 1509, 1514 (1st Cir. 1983); United States v. Stanley, 416 F.2d 317, 318 (2d Cir. 1969); Chambers Constr. Co. v. Mitchell, 233 F.2d 717, 724 (8th Cir. 1956); Marchak v. Observer Publications, Inc., 493 F. Supp. 278, 282 (D.R.I. 1980); Marshall v. Sam Dell's Dodge Corp., 451 F. Supp. 294, 296 (N.D.N.Y. 1978); Usery v. Weiner Bros., 70 F.R.D. 615, 617-18 (D. Conn. 1976); Schultz v. Chalk-Fitzgerald Constr. Co., 309 F. Supp. 1255, 1257 (D. Mass. 1970).

The Fair Labor Standards Act defines an "employer" as:

[A]ny person acting directly or indirectly in the interest of an employer in relation to an employee and includes a public agency, but does not include any labor organization (other than when acting as an employer) or anyone acting in the capacity of officer or agent of such labor organization.

Fair Labor Standards Act of 1938, §3(d), 29 U.S.C. $\S 203(d)$ (1982). The definition of "person" under the Fair Labor Standards Act inclndes "an individual, partnership association, corporation, business trust, legal representative, or any organized group of persons." $I d$. $\S 3(\mathrm{a})$, 29 U.S.C. $\S 203(a)$. The courts that have imposed personal liability on corporate officers under the Fair Labor Standards Act have interpreted section 203 literally, and have found that corporate officers act "directly or indirectly in the interest of the employer." See, e.g., Donovan, 712 F.2d at 1510-14; Usery, 70 F.R.D. at 617-18. Even these cases, however, caution that the definition of "employer" in the Fair Labor Standards Act should not be read too literally. See Donovan, 712 F.2d at 513 ("Taken literally and applied in this context [the definition of "employer"] would make any supervisory employee, even those without any control over the corporation's payroll, personally liable for the unpaid or deficient wages of other employees.").

The similarities between the definitions of "employer" and "person" under the Fair Labor Standards Act and ERISA, see supra notes 16-17, are striking. Thus, the argument that the Fair Labor Standards Act and ERISA should be interpreted in a similar fashion does have some substance.

43. See Solomon v. Klein, 770 F.2d 352, 354 (3d Cir. 1985).

44. See Combs v. Indyk, 554 F. Supp. 573, 575 (W.D. Pa. 1982); Solomon v. Klein, 770 F.2d 352, 354 (3d Cir. 1985).

45. See H. Henn \& J. AleXander, LAws of CORPorations 343 (1983); see also Connors v. P \& M Coal Co., 801 F.2d 1373, 1377-78 (D.C. Cir. 1986) (emphasizing principle of limited liability in corporate law and refusing to impose personal liability under section 4201 in the absence of clear expression by Congress). But see supra note 42 (noting that many courts have held officers personally liable for the corporation's violations of the Fair Labor Standards Act). 
dards Act, to impose personal liability on officers as "employers."46 However, an analogy between ERISA and the Fair Labor Standards Act may be mappropriate even thougl the stated policy of ERISA on its face tends to support such an analogy.

Both the Fair Labor Standards Act and ERISA are designed to protect employee interests. Congress stated that the "policy of [ERISA is] to protect interstate commerce and the interests of participants in employee benefit plans and their beneficiaries." 47 The policy behind the Multiemployer Pension Plan Amendments Act, ${ }^{48}$ which amended ERISA, is to provide "reasonable protection for the interests of participants and beneficiaries of financially distressed multiemployer pension plans." 49 In addition, the definitions of "employer" and "person" in ERISA and the Fair Labor Standards Act are very similar. ${ }^{50}$ The fact that both Acts liave broad compensatory purposes and contain comparable definitions supports the argument that "corporate officers" are "employers" subject to personal hability under both Acts. ${ }^{51}$

An analogy between ERISA and the Fair Labor Standards Act may be inappropriate, however. First, the purposes of the two Acts differ in significant ways. The Fair Labor Standards Act seeks to ensure compliance with minimum wage requirements, ${ }^{52}$ and its goals are strictly compensation and deterrence. ${ }^{53}$ Imposing personal hability on corporate officers thus seems consistent with the Fair Labor Standards Act's narrow focus on deterring minimum wage violations and compensating employees for any abuses.

46. See, e.g., Massachusetts State Carpenters Pension Fund v. Atlantic Diving Co., No. 832872, slip op. at 9-10 (D. Mass. Oct. 12, 1984).

47. ERISA § 2(b), 29 U.S.C. § 1001(b) (1982).

48. 29 U.S.C. $\$ 1001 \mathrm{a}(\mathrm{c})(3)(1982)$.

49. Id.

50. See supra note 42 and accompanying text.

51. See, e.g., Massachusetts State Carpenters Pension Fund v. Atlantic Diving Co., No. 832872, slip op. at 9-10 (D. Mass. Oct. 12, 1984); Alman v. Servall Mfg. Co., No. 82-0746, slip op. at 3 (D. Mass. Apr. 9, 1984).

The United States Court of Appeals for the Third Circuit, however, has expressly rejected thc analogy between the Fair Labor Standards Act and ERISA. See Solomon v. Klein, 770 F.2d 352, 354-55 (3d Cir. 1985).

52. The policy of the Fair Labor Standards Act is set forth in 29 U.S.C. $\S 202(b)$ (1982):

It is declared to be the policy of this chapter, through the exercise by Congress of its power to regulate commerce among the several States and with foreign nations, to correct and as rapidly as practicable to eliminate the conditions above referred to in such industries with. out substantially curtailing employment or carning power.

Id. The conditions "above referred to" include low standards of living, unfair competition, labor disputes, and burdens on interstate commerce. See id. at § 202(a) (1982).

53. See generally H.R. REP. No. 909, 97th Cong., 2d Sess. 9-18 (1982) (discussing purpose of Fair Labor Standards Act and recommending the imposition of treble damages for Fair Labor Standards Act violations). 
ERISA has much broader purposes. ERISA has extensive administrative and regulatory provisions and is targeted at compensating beneficiaries and ensuring that funds are available. ${ }^{54}$ The Act is designed not only to aid the employee, but also to regnlate the admimistration of pension plans and to facilitate their growth. ${ }^{55}$ ERISA thus is much more multifaceted than the Fair Labor Standards Act and lacks its singleness of purpose. Accordingly, officer liability under ERISA is less supportable than it is under the Fair Labor Standards Act. Courts should impose personal liability only when the imposition of such liability clearly follows from the stated purpose of the legislation. ${ }^{56}$

Second, given the number and size of private pension plans, the potential liability of corporate officers is inucli greater for pension plan violations than for minimum wage violations. In the absence of an express congressional mandate, therefore, courts slould be more liesitant to impose personal liability on corporate officers under ERISA than under the Fair Labor Standards Act.

Third, the fact that the two Acts contam similar definitions of "employer" and "person" is not dispositive. Personal liability under the Fair Labor Standards Act can be viewed as an exception that courts have been reluctant to apply in other areas of labor law. For example, the Labor-

54. See, eg., 29 U.S.C. $\S \S 1021-1086$ (1982) (reporting, disclosure, participation, vesting, and funding requirements).

55. See H.R. Rep. No. 533, 93d Cong., 2d Sess. 1-2, reprinted in 1974 U.S. CODE CONG. \& ADMin. News 4639, 4640. The purposes of the Multiemployer Pension Plan Amendments Act include the following: "(1) to foster and facilitate interstate commerce, (2) to alleviate certain problems which tend to discourage the inaintenance and growth of multiemployer pension plans ... and (4) to provide a financially self-sufficient program for the guatantee of employee benefits under inultiemployer plans." 29 U.S.C. $\S 1001$ a(c) (1982). Senator Javits, one of ERISA's floor inanagers, cominented:

Under this bill, the Congress has developed a fair and feasible system of private pension plan regulation. And under this regulation, private plans will develop more rapidly than in the past because the Congress will have assured that pension pronises are kept and reasonable expectations built upon those promises are not disappointed.

Private pension and welfare reform legislation is not a panacea for dealing with the Inore subtle undercurrents of social unrest; but the enactment of this legislation will clearly establish a more positive climate of respect for, and affirmation of, the worker's contribntion to our economic progress. The establishment of this climate is indispensable if we are to Inaintain our economic growth and build greater confidence in our Nation's ability to weather the economic problems we now confront.

120 CONG. REC. 29,944 (1974).

56. See supra note 45 . The Supreme Court recently refused to expand the remedial provisions of section 502. See Massachusetts Mutual Life Ins. Co. v. Russell, 105 S. Ct. 3085, 3093 (1985). In denying the plaintiff's claim for extracontractual damages under section 502, the Court focused on the comprehensive nature of ERISA and declined to imply an extracontractual damages provision. The Court reasoned that the integrated and comprehensive nature of ERISA supports a presuinption that Congress deliberately omitted such a provision. Id. See infra notes $64-65$ and accompanying text. 
Management Relations Act57 contains definitions of "employer" and "person" very similar to those found in both the Fair Labor Standards Act and ERISA. ${ }^{58}$ However, courts and the National Labor Relations Board have refused to impose personal liability on officers of corporations for violations of the Labor-Management Relations Act. ${ }^{59}$

Although imposing personal liability on corporate officers might appear to be consistent with ERISA's purpose to ensure compensation for plan participants and beneficiaries, the analogy between the Fair Labor Standards Act and ERISA is more tenuous than the court in Massachusetts State Carpenters Pension Fund v. Atlantic Diving Co. 60 indicates. Because ERISA and the Fair Labor Standards Act are distinguishable in terms of their breadth and specific goals, the fact that a corporate officer is personally liable under the Fair Labor Standards Act is, by itself, sinply "too slender a reed" on which to base personal liability. ${ }^{61}$ The legislative history of ERISA contams no indicia of congressional intent to impose officer liability.62 Furthermore, the language of sections 3, 515, and 502 supports hability only if given a very literal reading. ${ }^{63}$ Courts must examine other sections of ERISA in order to determine congressional intent on the issue of officer liability.

57. 29 U.S.C. $\S \S 141-188$ (1982).

58. See 29 U.S.C. $§ 152$ (1982). This section provides:

The term "person" includes one or more individuals, labor organizations, partnerships, associations, corporations, legal representatives, trustees, trustees in bankruptcy or receivers. ... The term "employer" includes any person acting as an agent of an employer, directly or indirectly.

For ERISA's definitions of "employer" and "person," see supra notes 16-17. For the Fair Labor Standards Act's definitions of the same terms, see supra note 42.

59. See, e.g., Carpenters Health \& Welfare Fund v. Kenneth R. Ambrose, Inc., 727 F.2d 279, 283-84 (3d Cir. 1983); Combs v. Indyk, 554 F. Supp. 573, 574-75 (W.D. Pa. 1982); see also Metropolitan Bureau of Investigation, Inc., 246 N.L.R.B. 544, 544 n.1 (1979); Chef Nathan Sez Eat Here, Inc., 201 N.L.R.B. 343, 343 (1973); Riley Aeronautics Corp., 178 N.L.R.B. 495, 495 (1969).

The refusal to extend personal liability to corporate officers as "employers" under the LaborManagement Relations Act also supports the first argument raised in this section: that although the narrow policy of the Fair Labor Standards Act-to compensate and deter-is consistent with the imposition of personal liability, personal liability is inappropriate where the purpose of the act is not primarily compensatory.

The Labor-Management Relations Act, unlike the Fair Labor Standards Act, is not primarily compensatory in nature. Rather, its purposes are broader: "[T]o establish a climate within which employees can freely determine whether they wish to collectivize their employment relationship; to provide for free collective bargaining, which means freedom of contract between employer and union; and thereby, to promote industrial peace." H. Wellington, LABOR AND THE LEgal ProCEss 45 (1968). See also 29 U.S.C. $\S 151$ (1982). ERISA has both compensatory and administrative features and falls somewhere between the Fair Labor Standards Act and the Labor-Management Relations Act in terms of compensatory purpose.

60. No. 83-2872, slip op. at 9-10 (D. Mass. Apr. 9, 1984).

61. See Combs v. Indyk, 554 F. Supp. 573, 575 (W.D. Pa. 1982).

62. See supra notes $43-45$ and accompanying text.

63. See supra notes $34-42$ and accompanying text. 
4. Other Sections of ERISA. None of the cases addressing officer liability under sections 502 and 515 have made any attempt to derive congressional intent from other sections of ERISA. Yet the liability sections of ERISA, taken together, indicate that courts should not hold officers personally liable for section 515 violations.

ERISA's detailed and comprehensive remedial scheme provides strong evidence that Congress did not intend that the Act's provisions be hiberally interpreted. A recent decision by the Supreme Court is instructive in this respect. In Massachusetts Mutual Life Insurance Co. v. Russell, 64 the Court refused to imply hability for extracontractual damages from sections 409 and 502 of ERISA. In so domg, the Court empliasized the compreliensive nature of ERISA's civil hability provisions:

The six carefully-integrated civil enforcement provisions found in $\S 502(a)$ of the statute as finally enacted ... provide strong evidence that Congress did not intend to authorize other remedies that it forgot to incorporate expressly. The assumption of inadvertant omission is rendered especially suspect upon close consideration of ERISA's interlocking, interrelated, and interdependent remedial scheme, which is in turn part of a comprehensive and reticulated statute. We are reluctant to "fine-tune" an enforcement scheine crafted with such evident care as the one in ERISA. Where a statute expressly provides a particular remedy or remedies, a court must be chary of reading others into it. The presumption that a remedy was deliberately omitted from a statute is strongest when Congress has enacted a comprehensive legislative scheme including an integrated system of procedures for enforcement. ${ }^{65}$

The same can be said of an attempt to "read in" a provision imposing personal liability on corporate officers under sections 502 and 515. ERISA's civil liability sections are simply too detailed and comprehensive to allow such an interpretation.

This argument gains force when the fiduciary liability provisions of ERISA $^{66}$ are examined alongside section 515. Section 404(a) imposes a "prudent man standard of care" on the fiduciary to "discharge his duties with respect to a plan solely in the imterest of the participants and beneficiaries." 67 A fiduciary who breaches this duty of care, or violates any of
64. 105 S. Ct. 3085 (1985).
65. Id. at 3093 (citations omitted).
66. ERISA $\S \S 404-409,29$ U.S.C. $\S \S 1104-1109$ (1982).
67. Id. § 404(a), 29 U.S.C. § 1104(a). This section provides:

[A] fiduciary shall discharge his duties with respect to a plan solely in the interest of the participants and beneficiaries and-(A) for the exclusive purpose of: (i) providing benefits to participants and their beneficiaries; and (ii) defraying reasonable expenses of administering the plan; (B) with the care, skill, prudence, and diligence under the circumstances then prevailing that a prudent man acting in a like capacity and familiar with such matters Id. would use in the conduct of an enterprise of a like character and with like aims .... 
the other fiduciary obligations specified in ERISA, ${ }^{68}$ is personally liable under section 409(a) for any losses to the plan resulting from such breach. ${ }^{69}$ Actions to enforce section 409 can be brought under section 502 by the Secretary of Labor, or a participant, beneficiary or fiduciary of the plan. ${ }^{70}$

The legislative history indicates that Congress believed that these fiduciary obligations would serve to control abuse in pension plan administration. ${ }^{71}$ However, the fact that personal liability is imposed on fiduciaries under section 409 gives rise to an inference that corporate officers should not be held personally liable. Because Congress specifically provided that fiduciaries are personally liable under section 409, without similarly extending personal hability to corporate officers under section 515 , courts should infer that Congress did not wish to impose personal hability on officers. ${ }^{72}$

68. Other fiduciary duties enumerated in the Act include: the duty to prevent a breach by a cofiduciary, ERISA $\S 405,29$ U.S.C. $\$ 1105$ (1982); the duty not to engage in prohibited transactions, id. $\S 406,29$ U.S.C. $\$ 1106$; and the duty not to purchase more than specified amounts of employer property or securities, id. $\S 407,29$ U.S.C. $\S 1107$.

69. Id. $\S 409$ (a), 29 U.S.C. $\S 1109$ (a). This section provides:

Any person who is a fiduciary with respect to a plan who breaches any of the responsibilities, obligations, or duties imposed upon fiduciaries by this subchapter shall be personally liable to make good to such plan any losses to the plan resulting from each such breach, and to restore to such plan any profits of such fiduciary which have been made througli use of assets of the plan by the fiduciary, and shall be subject to such other equitable or remeId. dial relief as the court may deem appropriate, including removal of such fiduciary.

70. Id. $\S 502(a), 29$ U.S.C. $\S 1132(a)$.

71. The fiduciary obligations, coupled with the civil enforcement provisions of section 502, were considered "broad remedies for redressing or preventing violations of the Act," and were intended "to provide the full range of legal and equitable remedies available in both state and federal courts and to remove jurisdictional and procedural obstacles which in the past appear to have hampered effective enforcement of fiduciary responsibilities under state law for reeovery of benefits due to participants." H.R. REP. No. 533, 93d Cong., 1st Sess. 17, reprinted in 1974 U.S. CODE CoNG. \& ADMIN. News 4639, 4655. See also S. REP. No. 127, 93d Cong., 1st Sess. 35, 37, 47.48, reprinted in 1974 U.S. Code Cong. \& ADMIN. News 4838, 4869, 4871, 4881-82; H.R. REP. No. 1280, 93d Cong., 2d Sess. 294-321, reprinted in 1974 U.S. CODE CONG. \& ADMIN. NEws 5038, 5075-101.

72. This form of argument is commonly referred to as expressio unius est exclusio alterius"the express mention of one thing is the exclusion of another." As the Supreme Court has stated:

The presumption that a remedy was deliberately omitted from a statute is strongest when Congress has enacted a comprehensive legislative scheme including an integrated system of procedures for enforcement.... The judiciary may not, in the face of such comprehensive legislative schemes, fashion new remedies that might upset carefully considered legislative programs.

Northwest Airlines, Inc. v. Transport Workers Union, 451 U.S. 77, 97 (1981). See also Transamerica Mortgage Advisors, Inc. v. Lewis, 444 U.S. 11, 19 (1979) ("[A]n elemental canon of statutory construction [is] that where a statute expressly provides a particular remedy or remedies, a court must be chary of reading others into it."). 


\section{B. Limits on Officer Liability.}

Even if a court does hold that an officer is an "employer" for purposes of sections 3 and 515, it does not necessarily follow that the court should hold the officer personally hable for delinquent contributions. An officer should not be hable unless the terms of the pension plan or collective bargaining agreement so provide.

Section 515 limits the duty to pay contributions to those employers "who [are] obligated to make contributions to a multiemployer plan under the terms of the plan or under the terms of a collectively bargained agreement."73 Therefore, unless the officer is deemed an "employer" and the pension plan or collectively bargained agreenent expressly or impliedly imposes an obligation on the officer to make contributions to the plan or assume liability if the contributing employer defaults, the officer should be free froin section 515 liability. ${ }^{74}$

This limitation on section 515 liability is consistent with the view that the civil liability sections of ERISA impose contractual liability, rather than tort liability. ${ }^{75}$ The court's focus should be on determining which parties assumed an express or implied contractual duty to make contributions to the plan, and only those parties should be liable in the event of a delinquency. ${ }^{76}$

\section{When Should a Corporate Officer Be Held Personally Liable?}

This note does not suggest that corporate officers should never be held personally liable under ERISA; it only suggests that corporate officers should not be held personally hable solely on account of their sta-

73. ERISA § 515, 29 U.S.C. § 1145 (1982). See supra note 4.

74. No court has given force to this limiting provision when faced with the question of officer liability, however. Presumably, those courts that have held that an officer can be liable under section 515 have overlooked section 515's limiting provision. One court simply stated that the lack of a "contractual obligation" on the part of the defendant was not dispositive of the matter. Alman v. Frank's Sportswear Co., 6 Employee Benefits Cas. (BNA) 2798, 2800 (D. Mass. 1985). Nonetheless, the express wording of section 515 strongly supports the argument that courts should not impose personal liability on an officer in the absence of contractual liability, even if the officer is considered an "employer."

75. See Massachusetts Mutual Life Ins. Co. v. Russell, 105 S. Ct. 3085, 3093 (1985) (fiduciaries are not subject to extracontractual liability under sections 409 and 502); Carpenters Local Union No. 1846 v. Pratt-Farnsworth, Inc., 511 F. Supp. 509, 514-15 (E.D. La. 1981) (contractors' association not liable under section 515 absent a contractual obligation in collective bargaining agreement to make contributions), aff'd in part, rev'd in part, 690 F.2d 489 (5th Cir. 1982), cert. denied, 464 U.S. 932 (1983).

76. The legislative history of section 515 is silent as to the purpose of the limiting phrase of the section. 
tus as corporate officers. Situations do exist when an officer should be held personally hable.

\section{A. Facts Supporting a Piercing of the Corporate Veil.}

First, a corporate officer can be held personally liable under section 515 when the officer is a shareholder and the facts support a piercing of the corporate veil. ${ }^{77}$ In such a case, the court finds that the corporation is a sham and holds the defendant, who is usually the majority shareholder as well as the chief executive officer or director, liable as the "employer."78 Typically, the corporate veil is pierced once the court finds a fraudulent intent on the part of the incorporators. ${ }^{79}$

\section{B. Fiduciary Liability.}

A corporate officer can be held personally liable under section $409(\text { a })^{80}$ if the court determines that the officer is a fiduciary and has breached one of the fiduciary duties set out in ERISA. ${ }^{81}$ The definition of a "fiduciary" contained in section $3(21)(A){ }^{82}$ is very broad, and as one commentator stated:

The broad and encompassing conceptual definition of "fiduciaries" in Section $3(21)(A)$ has succeeded in snaring most persons involved in the establishment, operation, and administration of these plans. The thrust of Section $3(21)(\mathrm{A})$ is that any person who possesses or exercises

77. In fact, those courts that have refused to hold an officer liable as an "employer" under section 515 have done so on the ground that piercing the corporate veil either was not warranted or had not been pleaded by the plaintiff. See Solomon v. Klein, 770 F.2d 352, 353-54 (3d Cir. 1985) (veil-piercing not warranted by facts); Amalgamated Cotton Garment \& Allied Indus. Fund v. J.B.C. Co., 608 F. Supp. 158, 167 (W.D. Pa. 1984) (same); United Paperworkers Int'l Union v. Arlington Sample Book Co., No. 83-2828, slip op. at 7 n.2 (E.D. Pa. May 23, 1984) (plaintiffs failed to allege facts and present arguments for piercing the veil); Combs v. Indyk, 554 F. Supp. 573, 574 (W.D. Pa. 1982) (veil-piercing not warranted by facts).

78. For a discussion of the factors that support veil-piercing, see supra note 7.

79. For ERISA cases involving this doctrine, see Alunan v. Danin, 801 F.2d 1 (1st Cir. 1986) (sole shareholders and directors held personally liable); Greater Kansas City Laborers Pension Fund v. Thunmel, 738 F.2d 926, 929-30 (8th Cir. 1984) (sole stockholder held personally liable); and Laborers Clean-Up Contract Admin. Trust Fund v. Uriarte Clean-Up Serv., Inc., 736 F.2d 516, 52324 (9th Cir. 1984) (same).

80. ERISA § 409(a), 29 U.S.C. § 1109(a) (1982). See supra notes $68-69$ and accompanying text.

81. See supra notes $66-67$ and accoinpanying text.

82. ERISA $\S 3(21)(A), 29$ U.S.C. $\S 1002(21)(A)$ (1982). This section provides:

A person is a fiduciary with respect to a plan to the extent (i) he exercises any discretionary authority or discretionary control respecting management of such plan or exercises any authority or control respecting management or disposition of its assets, (ii) he renders investment advice for a fee or other compensation, direct or indirect, with respect to any moneys or other property of such plan, or has any authority or responsibility to do so, or (iii) he has any discretionary authority or discretionary responsibility in the administration Id. of such plan. 
any fiduciary control, responsibility, or authority with regard to the operation, administration, or management of a plan or its assets is a fiduciary. ... Thus, Congress declared and the [Department of Labor] has pursued the concept that fiduciary status is determined not by labels, but by conduct. ${ }^{83}$

This broad definition of "fiduciary" has been liberally interpreted to include any corporate officer who exercises authority or discretionary control over the plan's management, assets, or administration. ${ }^{84}$ Such a broad application of fiduciary hability is consistent with Congress' express imtent to curtail fiduciary misconduct by providing broad remedies. ${ }^{85}$

In Evans v. Penn, ${ }^{86}$ the United States Court of Appeals for the Tenth Circuit held that Penn, an officer and director of the contributing corporation, was hable as a fiduciary because he had given investment advice and aided im "recommending, designing and implementing amendment of the original profit-sharing plan to an einployee stock ownership plan."87 The United States Court of Appeals for the Seventh Circuit, in Leigh v. Engle, ${ }^{88}$ held that the supervisor of the employees responsible for the manageinent of a trust was himself a fiduciary. Similarly, courts have found corporate officers to be fiduciaries if they had responsibility for selecting and retaining the plan trustees. ${ }^{89}$ A corporate officer may thus be personally hable under section 409(a) for any loss to the plan if the loss is due to a breach of a fiduciary duty owed by that officer. ${ }^{90}$

83. Gertner, ERISA in Retrospect, $10 \mathrm{~J}$. Pension Plan. \& Compliance 275, 276 (1984).

84. See Shaw v. International Ass'n of Machinists \& Aerospace Workers Pension Plan, 563 F. Supp. 653, 657 (C.D. Cal. 1983), aff'd, 750 F.2d 1458 (9th Cir.), cert. denied, 105 S. Ct. 2678 (1985); see also Donovan v. Mercer, 747 F.2d 304, $308-09$ (5th Cir. 1984) (individual who signed documents and took actions regarding plan in official capacity was a fiduciary); Monson v. Century Mfg. Co., 739 F.2d 1293, 1303-04 (8th Cir. 1984) (individual who exercised discretionary authority over plan was a fiduciary). For discussions of the definition of "fiduciary," see Gertner, supra note 83, at 27677; Lee, Multiple Legal Representation of ERISA Plans and Employers Following Allegations of Fraud and Malfeasance, 57 IND. L.J. 537, 545 (1981); Little \& Thrailkill, Fiduciaries Under ERISA: A Narrow Path to Tread, 30 VAND. L. REV. 1, 4-10 (1977); and Pillsbury, Employee Benefit Plan Claims Under ERISA, 55 CONN. B.J. 357, 374-75 (1981). Under the Department of Labor regulations, a director is often considered a fiduciary. See 29 C.F.R. $\$ 2509.75-78$ (1985).

85. See supra note 71 .

86. 587 F.2d 453 (10th Cir. 1978).

87. Id. at $458-59$.

88. 727 F.2d 113, 134-35 (7th Cir. 1984).

89. See, e.g., Shaw v. International Ass'n of Machinists \& Aerospace Workers Pension Plan, 563 F. Supp. 653, 657 (C.D. Cal. 1983), aff'd, 750 F.2d 1458 (9th Cir.), cert. denied, 105 S. Ct. 2678 (1985).

90. See supra note 69 and accompanying text. Owing to the nature of multiemployer plans, however, it may be difficult for a corporate officer to exercise sufficient control over a multiemployer plan to be deemed a "fiduciary." 
Although this note questions the reasoning found in those decisions that have held that a corporate officer is an "eniployer" under sections 3 and 515, the result reached in sonie of those cases niay have been correct. For exainple, in Alman v. Servall Manufacturing Co., ${ }^{91}$ the facts, as related in the opinion, indicate that the defendant corporate officer was a fiduciary: he "acted on behalf of [the contributing corporation] in all matters having to do with the benefit plans, including audits, ascertaining contributions and collection arrangeinent."92 The plaintiff, however, did not allege that the officer was a fiduciary or that he had breached his fiduciary duties. ${ }^{93}$

\section{Willful Violations.}

If an officer willfully violates any section of ERISA, thereby causing a delinquency, the officer can be hable under section 501.94 That section provides that "[a]ny person who willfully violates any provision of part 1 of this subtitle, or any regulation or order issued under any such provision, shall upon conviction be fined not n1ore than $\$ 5,000$ or imprisoned not more than one year, or both."95 Thus, in contrast to the liability of an officer under sections 515 or 409 , the liability of an officcr who has committed a willful violation is statutorily limited. ${ }^{96}$

\section{CONCLUSION}

Whether a corporate officer is an "einployer" under section 515 of ERISA will have a significant impact on the role of corporate officers in the function of pension plans. If an officer is an enployer under section 515 , the officer can be held hable for delinquent contributions. There are currently two coinpeting interpretations regarding the corporate officer's status under section 515.

91. No. 82-0746, slip op. (D. Mass. Apr. 9, 1984).

92. Id. at 2.

93. By the same token, the plaintiff in Solomon v. Klein, 770 F.2d 352 (3d Cir. 1985), might have succeeded had he brought an action against Klein, the officer, under a "fiduciary" theory rather than a "corporate officer" theory. The plaintiff alleged that Klein "acted for the corporation in all matters related to employee benefit plan funds, including payroll audits, calculation of contributions, making payment to the employee benefit funds, signing checks, paying the bills and dealing on behalf of the corporation directly with the employment benefit plans." Id. at 353. Although it thus appears that Klein played a fiduciary role, the plaintiff failed to make such a claim or allege that Klein breached his fiduciary duties.

94. ERISA § 501, 29 U.S.C. § 1131 (1982).

95. Id.

96. Ironically, if the Combs analysis-that an officer is not a "person" and is therefore not liable under section 515-is applied to section 501 liability, the officer could also cscape criminal sanctions despite his willful conduct, because section 501 limits criminal liability to "person[s]." See id. $\S 501,29$ U.S.C. $\S 1131$. 
This note has analyzed sections 3,502 , and 515 , the legislative history of ERISA, its purpose and policy, and the sections of ERISA that pertain to fiduciary hability. It proposes that courts should impose personal hability on corporate officers only (1) when the officer's conduct constitutes a "willful violation" under section 501, (2) when the officer is a fiduciary and has breached the duty under section 409 , or (3) when the officer's conduct is such that a piercing of the corporate veil is warranted. Accordingly, this note rejects the position of those courts that hold that a corporate officer is an "employer" subject to joint and several liability with the contributing corporation under section 515 .

Scott A. Cammarn 